\title{
Free Vibration Analysis of Composite Plate Stiffened by Lattice Structures
}

\author{
Serkan Güler* \\ * Iskenderun Technical University, Faculty of Engineering and Natural Sciences, Departmant of Mechanical Engineering, Hatay, Turkey, \\ (ORCID: 0000-0002-1552-3432), serkan.guler@iste.edu.tr
}

(1st International Conference on Applied Engineering and Natural Sciences ICAENS 2021, November 1-3, 2021)

(DOI: 10.31590/ejosat.1002158)

ATIF/REFERENCE: Guler, S. (2021). Free Vibration Analysis of Composite Plate Stiffened by Lattice Structures. European Journal of Science and Technology, (28), 407-410.

\begin{abstract}
Free vibration behavior of laminated composite plates stiffened by different lattice structures is considered. To simulate free vibration, finite element models were created with Ansys Parametric Design Language (APDL). In the models, SHELL181 and BEAM181 elements were used to model laminated composite and lattice structures, respectively. The influence of the different stiffeners lattice structures on natural frequencies of the composite plate is examined for the clamped-free-clamped-free boundary condition. The results showed that the frequency parameters of the stiffened composite structures made of the L2-type lattice are higher than those composed of other lattice types. This study provides an exciting opportunity to advance our knowledge of the usage of lattice structures as stiffener structures for composite plates.
\end{abstract}

Keywords: Composite, Stiffened plate, Free vibration, Finite element method, Lattice structures.

\section{Kafes Yapılarla Pekiştirilmiş Kompozit Plakanın Serbest Titreşim Analizi}

$\ddot{\mathbf{O z}}$

Farklı kafes yapıları ile pekiştirilmiş tabakalı kompozit plakaların serbest titreşim davranışı incelenmiştir. Serbest titreşimi simüle etmek için, Ansys Parametric Design Language (APDL) ile sonlu eleman modelleri oluşturulmuştur. Modellerde tabakalı kompozit ve kafes yapıların modellenmesinde sırasıyla SHELL181 ve BEAM181 elemanları kullanılmıştır. Farklı pekiştirici kafes yapılarının kompozit plakanın doğal frekansları üzerindeki etkisi, ankastre-serbest-ankastre-serbest sınır koşulu için incelenmiştir. Sonuçlar, L2 tipi kafesten yapılan pekiştirilmiş kompozit yapıların frekans parametrelerinin diğer kafes tiplerinden oluşanlardan daha yüksek olduğunu göstermiştir. Bu çalışma, kafes yapılarının kompozit plakalar için pekiştirici yapıları olarak kullanımına ilişskin bilgimizi artırmak için ilgi çekici bir firsat sunmaktadır.

Anahtar Kelimeler: Kompozit, Pekiştirilmiş plaka, Serbest titreşim, Sonlu eleman metodu, Kafes yapılar. 


\section{Introduction}

Thin-walled structures are broadly used to build aerospace structures in the aerospace industry. To produce thin-walled structures, composite materials are commonly utilized due to their outstanding lightweight and strength. Although the thin-walled composite structures have strong tensile strength, they need reinforcing for shear, compression, and bending loads [1]. Using stiffeners is frequently preferred to reinforce the composite structures in the aerospace industry [2]-[4].

In the design period, predicting the resonance frequencies of any engineering structure is critical to avoid undesirable damages such as crack and fatigue, etc. The free vibration analysis is commonly utilized for calculating the natural frequencies of the engineering structure that may result in resonances. The finite element method is a trustworthy method for predicting dynamic responses for different sorts of engineering structures [5]. In this regard, the present study is concerned with the influences of different stiffeners lattice structures on natural frequencies of the composite plate for the clamped-clamped boundary condition. Therefore, the literature review is summarized in two sections. The first part is regarding the vibration of composite stiffened plates and the second is devoted to lattice structures.

There are numerous research articles concerning stiffened composite plates. Amongst these, Bhar et al. [6] performed finite element analysis of laminated composite stiffened plates. In this study, they used higher-order shear deformation theory and the first-order shear deformation theory to conduct static and free vibration analyses. Huang et al. [7] proposed an effective finite element modeling method for stiffened laminated composite plates. To model stiffeners, a curved beam element compatible with the shell element was introduced in the model. Damnjanović et al. [8] performed free vibration analysis of composite stiffened plates using the dynamic stiffness method based on the higherorder shear deformation theory. In another article, the influences of the transverse shear deformation and the rotary inertia are considered for free vibration analysis of stiffened and cracked laminated composite plate assembly [9]. Zhang and $\mathrm{Xu}$ [10] calculated the static deformation of eccentrically stiffened plates. The stiffened plates were modelled plate and beam elements that are discretely connected to the plate elements for inquiring the eccentricity. Rajawat et al. [11] carried out the free vibration analysis of stiffened laminated plate using APDL. In the analysis, SHELL181 element was used to model composite plate. The consequences of the eccentricity of the stiffener, the number of stiffeners, and its positions were investigated on natural frequencies in that study. Geng et al. [12] proposed a new numerical scheme to determine the stiffened-plate composite structures' mid-frequency and dynamic response. Balkan et al. [13] examined the nonlinear dynamic behavior of a laminated composite stiffened plate subjected to the non-uniform blast and load. In this study, a composite sandwich beam was used as a stiffener. Sinha et al. [14] determined the effects of numbers, types and orientation of stiffeners, depth of stiffener to the thickness of plate ratio, and aspect ratio and boundary conditions of plates on natural frequencies of the composite stiffened plates. They also established a finite element model of composite stiffened plate for computing natural frequencies. Investigation of composite stiffened plates is still active research area [15]-[18]. In recent years, although much more information has become available on composite stiffened plates, there is limited study dealing with free vibration analysis of composite plate stiffened by lattice structures to the best of the author's knowledge.

This study intends to analyse the effects of different lattice structures, which are used as stiffeners, for free vibration analysis of composite plate stiffened. Therefore, the literature on lattice structures is summarized as follow. Progression in additive manufacturing technology has brought about lattice structures that have a lightweight and mechanical efficiency ratio [19]-[22]. Most of the published studies have attempted to optimize latticestructural materials [23], [24]. Azzouz et al. [25] examined the role of the three lattice structures' shapes on the compression, shear and bending strength. Yang et al. [26] provided an analytical method to divine the mechanical properties of sandwich lattice structures. In that study, a finite element model of the sandwich lattice structures was developed by using Timoshenko beam theory to predict deformation patterns. Yang et al. [27] evaluated the use of vibration-based defect recognition composite sandwich panels with corrugated lattice cores. They investigated how effects different sorts of flaws on modal characteristics by developing a finite element model in ABAQUS software. An et al. [28] tested the effectiveness of meta-truss lattice composite structures for providing vibration attenuation.

Thus, this article has aimed to assess the using different lattices as stiffeners for stiffened composite plates and their association with natural frequencies.

\section{Finite Element Modeling}

In this article, free vibration analysis of laminated composite plates stiffened with three different lattice structures was performed to determine their natural frequencies. The finite element method is a popularly practised technique to predict engineering structures' behaviour. Therefore, to calculate natural frequency, finite element models of stiffened laminated composite plates were generated. In the models, the ANSYS Parametric Design Language platform was used to establish the finite element models. The laminated composite plates and the lattices were meshed using SHELL181 finite elements and BEAM188 finite elements respectively.

To construct the finite element model of stiffened composite plates, firstly, three sorts of lattice structures were created. Figure 1 shows the line models of stiffeners lattices' cell structures, the dimensions are shown that used in the FE model in Figure 2. The lattices' cells were labelled with $L_{i}(i=1,2,3)$.

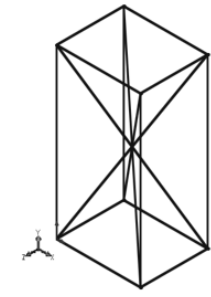

(a)

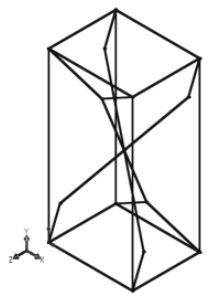

(b)

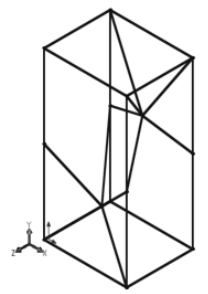

(c)
Figure. 1 Lattices' cell structures, (a) $L_{1}$, (a) $L_{2}(b), L_{3}(c)$.

In Figure 2, " $r$ " represents the diameter of the beam of lattices cells, " $b$ ", " $h$ " and " $t$ " indicate the width, height and thickness of the lattices' cells respectively. 


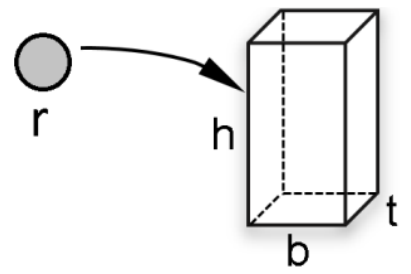

Figure 2. Dimensions of lattices and cross-section of the lattice beam.

The stiffened composite plates models were established as rectangles (see Figure 3). The schematic view of utilized symmetric lay-ups of the composites is illustrated in Figure 4. The ply angles of the composite plates were specified as $\left[90^{\circ},-45^{\circ}\right.$, $\left.45^{\circ}, 90\right]$.

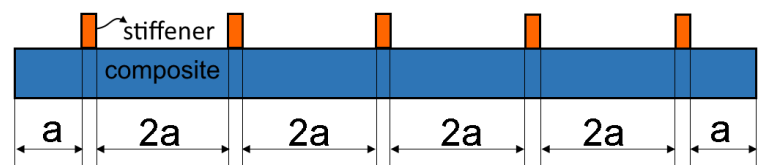

Figure 3. Exemplified illustration of the stiffened composite plates.

In Figure 3, the blue rectangle and orange rectangles illustrate composite plate and lattice structures respectively. Here, the offset between each stiffener, " $a$ ", was described as $a=k_{b} \cdot b$. The width and length of the composite plate can be calculated as follow $B=10 \cdot a+5 \cdot t$ and $H=k_{h} \cdot h$, respectively.

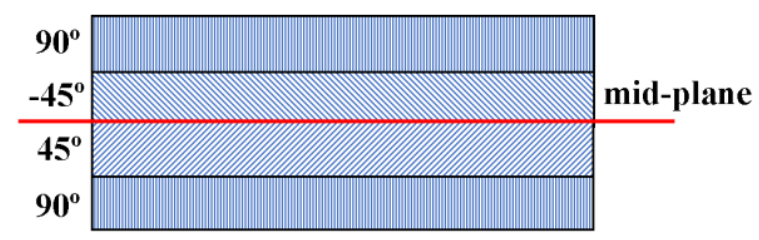

Figure 4. Angular lay-ups of the composite plates.

In the finite element models, stiffeners were constructed by placing " $k_{h}$ " pieces of cells next to each other with the " $h$ " side of the cell in the vertical position in the direction of the z-axis. In each finite element model, 5 stiffeners were used (see Figure 5) to construct stiffened composite plates. Simulations were carried out for the clamped-free-clamped-free boundary conditions.

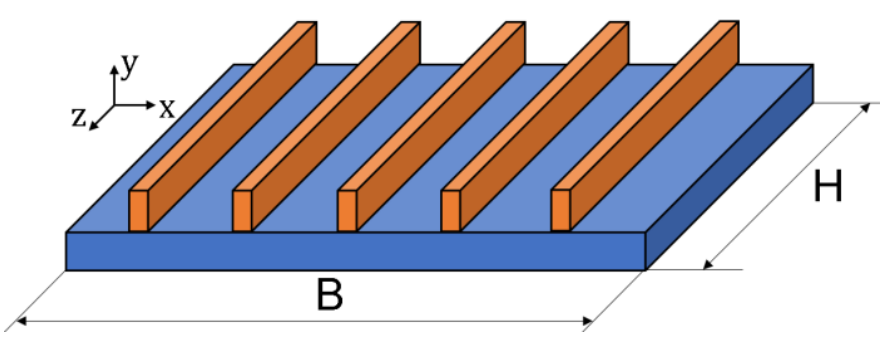

Figure 5. 3D view of the composite plate with the stiffeners.

\section{Results and Discussion}

Computed natural frequencies are presented by the natural frequency parameter that is defined as follow;

$$
\mu_{i}=\frac{f_{i}}{m_{L}}
$$

where, " $f_{i}$ " $(\mathrm{Hz})$ and " $m_{L}$ " represent natural frequencies of the stiffened composite plates corresponding to the first three e-ISSN: 2148-2683 fundamental bending modes in the $\mathrm{x}-\mathrm{z}$ plane and the total mass of all stiffeners in the structure respectively.

Material properties of composite plates are $E_{1}=44.9 \mathrm{GPa}, E_{2}=$ $12.32 \mathrm{GPa}$ and $\rho_{C}=2000 \mathrm{kgm}^{-3}$. Here, $E_{1}$ and $E_{2}$ are Young's modulus along the fibre and Young's modulus transverse the fibre respectively. The material properties of stiffeners made of Polylactic acid (PLA) are $E_{L}=2 \mathrm{GPa}$ and $\rho_{L}=1230 \mathrm{kgm}^{-3}$.

Dimensions of the lattice cells were specified as $t=10 \mathrm{~mm}$, $h=b=25 \mathrm{~mm}, k_{b}=8$ and $k_{h}=20$ for the stiffened composite structures.

The effects of the usage of the different lattices' cells the natural frequency parameters are demonstrated in Table 1 and 2. These results are given for the $r=1 \mathrm{~mm}$ and $r=2 \mathrm{~mm}$ diameter lattice beam.

Table 1. Natural frequency parameters for $r=1 \mathrm{~mm}$.

\begin{tabular}{ccccc}
\hline \multirow{2}{*}{$\begin{array}{c}\text { Vibration } \\
\text { plane }\end{array}$} & \multirow{2}{*}{$\begin{array}{c}\text { Lattice } \\
\text { type }\end{array}$} & \multicolumn{3}{c}{$\begin{array}{c}\text { Natural frequency } \\
\text { parameters }\end{array}$} \\
\cline { 2 - 5 } & 1 & 62.54 & 172.29 & 338.03 \\
\cline { 2 - 5 } & & & $\boldsymbol{\mu}_{\mathbf{1}}$ & $\boldsymbol{\mu}_{\mathbf{3}}$ \\
\hline $\begin{array}{c}\text { Bending } \\
(x-z)\end{array}$ & 2 & 64.86 & 178.67 & 350.55 \\
\cline { 2 - 5 } & 3 & 59.02 & 162.59 & 319.04 \\
\hline
\end{tabular}

It is observed that all the frequency parameters of the stiffened composite structures built from the $L_{2}$-type lattice are greater than those constructed with other lattice types when Table 1 considered. A similar trend can be seen in Table 2 for the $2 \mathrm{~mm}$ diameter lattice beam.

Table 2. Natural frequency parameters for $r=2 \mathrm{~mm}$.

\begin{tabular}{ccccc}
\hline \multirow{2}{*}{$\begin{array}{c}\text { Vibration } \\
\text { plane }\end{array}$} & \multirow{2}{*}{$\begin{array}{c}\text { Lattice } \\
\text { type }\end{array}$} & \multicolumn{3}{c}{$\begin{array}{c}\text { Natural frequency } \\
\text { parameters }\end{array}$} \\
\cline { 2 - 5 } & 1 & 14.43 & 39.73 & 78.01 \\
\cline { 2 - 5 } & & $\boldsymbol{\mu}_{\mathbf{1}}$ & $\boldsymbol{\mu}_{\mathbf{2}}$ & $\boldsymbol{\mu}_{\mathbf{3}}$ \\
\hline $\begin{array}{c}\text { Bending } \\
(x-z)\end{array}$ & 2 & 15.01 & 41.32 & 81.12 \\
\cline { 2 - 5 } & 3 & 13.57 & 37.40 & 73.43 \\
\hline
\end{tabular}

\section{Conclusions and Recommendations}

The present study was designed to determine the effect of the different stiffeners lattice structures on natural frequencies of the composite plate to examine for the clamped-free-clamped-free boundary condition.

The results of this study indicate that the frequency parameters of the stiffened composite plates composed of the $L_{2}$ type lattice are greater than those constructed by other lattice types. The results pointed out these designed stiffened composite structures may be used in many sorts of fields such as aeronautics, aerospace, construction and more. 


\section{References}

[1] Haim Abramovich, Ed., Stability and Vibrations of ThinWalled Composite Structures, Cambridge, United Kingdom: Woodhead Publishing, 2018.

[2] T. I. Thinh and N. N. Khoa, "Free vibration analysis of stiffened laminated plates using a new stiffened element", Technische Mechanik, vol. 28, pp. 227-236, Oct. 2008.

[3] A. Cankurt, "Optimum design of composite stiffened panels with instability considerations," M. Eng. thesis, The Graduate School of Natural and Applied Sciences of Middle East Technical University, Ankara, India, Sept. 2013.

[4] S. Sahoo, Design Aids for Stiffened Composite Shells with Cutouts, Springer, Singapore, 2017.

[5] S.S. Rao, Vibration of Continuous Systems, John Wiley \& Sons, Inc. Hoboken, New Jersey (2007).

[6] A. Bhar, S.S. Phoenix, S.K. Satsangi, "Finite element analysis of laminated composite stiffened plates using FSDT and HSDT: A comparative perspective", Composite Structures, vol. 92, pp. 312-321, Aug. 2010.

[7] L. Huang, A. H. Sheikh, C.T. Ng, M.C. Griffith, "An efficient finite element model for buckling analysis of grid stiffened laminated composite plates", Composite Structures, vol. 122, pp. 41-50, Nov. 2015.

[8] E. Damnjanović, M. Nefovska-Danilović, M. Petronijević, M. Marjanović, "Application of the dynamic stiffness method in the vibration analysis of stiffened composite plates", Procedia Engineering, vol. 199, pp. 224-229, Sept. 2017.

[9] E. Damnjanović, M. Marjanović,M. Nefovska-Danilović, "Free vibration analysis of stiffened and cracked laminated composite plate assemblies using shear-deformable dynamic stiffness elements", Computer Structures, vol. 180, pp. 723-740, Nov. 2017.

[10] S. Zhang, L. Xu, "Exact static analysis of eccentrically stiffened plates with partial composite action", Composite Structures, vol. 198, pp.117-125, May 2018.

[11] A. S. Rajawat, A. K. Sharma, P. Gehlot, "Free vibration analysis of Stiffened Laminated Plate using FEM", Materials Today: Proceedings, vol. 5, pp.5313-5321, Mar. 2018.

[12] J. Geng, X. Zhang, C. Wang, Y. He, X. Chen, "Predicting dynamic response of stiffened-plate composite structures in a wide-frequency domain based on Composite B-spline Wavelet Elements Method (CBWEM)", International Journal of Mechanical Sciences, vol. 144, pp.708-722, Jun. 2018.

[13] D. Balkan, Ö. Demir, A. Arıkoğlu, "Dynamic analysis of a stiffened composite plate under blast load: A new model and experimental validation", International Journal of Impact Engineering, vol. 143, pp. 103591, Sept. 2020.

[14] L. Sinha, S.S. Mishra, A.N. Nayak, S.K. Sahu, "Free vibration characteristics of laminated composite stiffened plates: Experimental and numerical investigation, Composite Structures, vol. 233, pp.111557, Oct. 2020.

[15] M. Zarei, G.H. Rahimi, M. Hemmatnezhad, "Free vibrational characteristics of grid-stiffened truncated composite conical shells", Aerospace Science and Technology, vol. 99, pp.105717, Jan. 2020.

[16] J. Chen, Y. Zhong, Q. Luo, Z. Shi, "Static and dynamic analysis of Isogrid Stiffened Composite Plates (ISCP) using equivalent model based on variational asymptotic method", Thin-Walled Structures, vol. 163, pp.107671, June 2021.
[17] Y. Wang, P. Qiao, "Improved buckling analysis of stiffened laminated composite plates by spline finite strip method", Composite Structures, vol. 255, pp.112936, January 2021.

[18] Y. Wang, P. Qiao, "Postbuckling analysis of orthogonallystiffened plates by a simplified spline finite strip method", Thin-Walled Structures, Vol. 166, pp.108122, September 2021.

[19] X. Liu, Y. Li, Y. Lin, J.R. Banerjee, "Spectral dynamic stiffness theory for free vibration analysis of plate structures stiffened by beams with arbitrary cross-sections", ThinWalled Structures, vol. 160, pp. 107391, March 2021.

[20] P. S. Lee and G. McClure, "Elastoplastic large deformation analysis of a lattice steel tower structure and comparison with full-scale tests", Journal of Constructional Steel Research, vol. 63, pp. 709-717, 2007.

[21] M. C. Messner, M. I. Barham, M. Kumar and N. R. Barton, "Wave propagation in equivalent continuums representing truss lattice materials", International Journal of Solids and Structures, vol.73-74, pp. 55-66, 2015.

[22] R. Guo, R. Liu, W. Jiang, K. Chen, J. Zhang, F. Huang and X. Sun, "Numerical Analysis on Static Mechanical Properties of the Periodic Multilayer Lattice Material," Engineering, vol. 3 (12), pp. 1149-1154, 2011.

[23] J. Sun, Y. Yang and D. Wang, "Mechanical properties of regular hexahedral lattice structure formed by selective laser melting", Laser Physics, vol. 23, 066101 (9pp), 2013.

[24] C. Pan, Y. Han, J. Lu, "Design and Optimization of Lattice Structures: A Review", Applied Sciences, vol.10(18),p. 6374, Sept. 2020.

[25] L. Azzouz, Y. Chen, M. Zarrelli, J. M. Pearce, L. Mitchell, G. Ren, M. Grasso, "Mechanical properties of 3-D printed truss-like lattice biopolymer non-stochastic structures for sandwich panels with natural fibre composite skins", Composite Structures, vol. 213, pp.220-230, Jan. 2019.

[26] Y. Yang, M. Shan, L. Zhao, D. Qi, J. Zhang, "Multiple strutdeformation patterns based analytical elastic modulus of sandwich BCC lattices", Materials \& Design, vol. 181, pp. 107916, 2019.

[27] J.S. Yang, Z.D. Liu, R. Schmidt, K.U. Schröder, L. Ma, L. $\mathrm{Z}$. Wu, "Vibration-based damage diagnosis of composite sandwich panels with bi-directional corrugated lattice cores", Composites Part A: Applied Science and Manufacturing, vol. 131, pp. 105781, Jan. 2020.

[28] X. An, C. Lai, W. He, H. Fan, "Three-dimensional metatruss lattice composite structures with vibration isolation performance", Extreme Mechanics Letters, vol. 33, pp. 100577, Sept. 2019. 